\title{
Communicative Behavior via Gender Identity (Based on the English language «Love Stories»)
}

\section{Мовленнєва поведінка комунікантів в контексті ґендерної ідентичності (на матеріалі англомовного любовного роману)}

Olga Adamenko ${ }^{1}$

Ph.D. in Philology, Assistant Professor
Ольга Адаменко ${ }^{1}$

кандидат філологічних наук, доцент

\section{E-mail: olam.zp@gmail.com https://orcid.org/0000-0002-0717-8843}

Olga Klymenko ${ }^{2}$

Ph.D. in Philology, Professor
Ольга Клименко 2

кандидат філологічних наук, професор

E-mail: olga.klymenko.zp@gmail.com

https://orcid.org/0000-0003-3081-6556

\author{
${ }^{1}$ National University \\ «Zaporizhzhia Polytechnics» \\ 64, Zhukovskoho Str., \\ Zaporizhzhia, Ukraine, 69063 \\ ${ }^{2}$ Zaporizhzhia National University \\ $\bowtie 66$, Zhukovskoho Str., \\ Zaporizhzhia, Ukraine, 69600
}

\begin{abstract}
${ }^{1}$ Наиіональний університет «Запорізька політехніка» $\square$ вул. Жуковського, 64, Запоріжжя, Україна, 69063

23апорізький національний університет вул. Жуковського, 66, Запоріжжя, Україна, 69600
\end{abstract}

Original manuscript received August 02, 2019

Revised manuscript accepted March 30, 2020 


\section{ABSTRACT}

The focus of the paper concerns the specific features of characters' communicative behavior via gender identity. This study deals with two types of correlation and interaction between real and fictional text-creating subjects: the gender identity of the author and the image created in the literary text.

The research procedure is based on the discourse analysis. The study proves the influence of psychological and socio-cultural factors on speech organization. Due to the combination of content- and elements of intent-analysis the author's pragmatic intentions in the communicative process are identified. The main findings of this paper are based on the theoretical basis of gender-specified communicative behavior study and the statistical data analysis.

As a result of the research the specific features of gender communicative style are defined. Besides it is claimed, that taboo words differentiate basic features of male and female speech. The further analysis of non-literary vocabulary proves that gender stereotypes in female-written novels determine the choice of language means for the creation of an ideal male and female image: neglect of moral rules (domination of taboo words provoking conflict and rivalry) or compliance of communicative norms (a rare usage of derogatory vocabulary, communication aimed at cooperation and interaction). Gender differentiation of taboo lexicon in male-written novels argues the conventional stereotype of using taboos mainly by men. The research paper represents the differences in male and female speech, connected with the phenomenon of gender stylization. It proves that style imitation of stereotypical features in the opposite-sex speech occurs in two directions: female authors imitate the masculine communicative style of characters by the domination of taboo words, whereas male authors imitate the feminine communicative style by softening expressions of both-sex characters.

Thus, in conclusion the study reveals imitating and identifying features of the author's natural gender identity, such as domination of taboo words like "damn» and "hell» in opposite-sex communication in male-written novels unlike communicative behavior of male and female characters in the novels written by women.

Key words: gender communicative behavior, gender communicative style, gender stylization, gender identity, feminine/masculine speech, character's speech, author's intention.

\section{Вступ}

Велика кількість методологічних i концептуальних напрямів у гуманітарних науках спричинили поліпарадигмальний статус сучасного лінгвістичного простору. Така глобалізація наукового знання, у свою чергу, сприяла формуванню нового інтегративного підходу, метою якого став синтез існуючих парадигм різних галузей, i як результат, виникнення нових «двоїстих» наук (психолінгвістика, 
соціолінгвістика), формування нових ланок та збільшення об'єктів вивчення в межах самої лінгвістики. Звернення до даних інших наук спирається на прагнення знайти пояснення мовним феноменам, у першу чергу, у сутнісних характеристиках iї носія. Принцип антропоцентризму полягає в проеціюванні людського фактора на всі теоретичні передумови наукового дослідження (Кубрякова, 1995).

Останнім часом гуманітарні студії все більше скеровують наукову увагу в бік вивчення впливу екзистенціальних параметрів особистості на мовні та мовленнєві явища. I такий чинник, як соціокультурна стать, стає вагомим критерієм у цьому процесі. Психолінгвістичні розробки гендерної теорії стосуються переважно вивченню своєрідності комунікативної поведінки чоловіків і жінок: виділяють головні принципи інтеракції різностатевих комунікантів (Крейдлин, 2005; Dovidio, Heltman, Brown, Ellyson \& Keating, 1988; Maltz \& Borker, 1982); з'ясовують гендерні розбіжності у виборі стратегій і тактик для досягнення успіху в процесі спілкування (Tannen, 1990, 1993); визначають гендерно специфічні мовні засоби (Горошко, 1996; Земская, 1993; Coates \& Cameron, 1989; Key, 1975; Lakoff, 1973); уділяють увагу репрезентації жіночності й мужності в мові (Кирилина, 1998; Гриценко, 2005), стереотипному уявленню про статево-рольові характеристики (Вет, 1993; Клецина, 2009; Steckler \& Rosenthal, 1985). Дискусії підлягає і вплив гендерного чинника на формування асоціативного поля інформантів (Горошко, 2001; Земская, 1993).

Окрему ланку психолінгвістичних розвідок крізь призму гендера займає вивчення особливостей демонстрації емоцій, досліджуються емотивно-експресивні властивості чоловічого i жіночого мовлення (Барышникова, 2004; Romaine, 1999). Доведено, що представники чоловічої та жіночої статі виявляють різні здібності у вербалізації своєї емоційності та по-різному іiі актуалізують (Иванова, 2011; Кузнєцов, 2015).

Значний дослідницький інтерес викликають особливості вербальної поведінки різновікових комунікантів. Постулюється гіпотеза взаємозалежності статі й соціального досвіду, їхній вплив на рівень та основні характеристики мовлення. Зокрема, відмічають особливості вибору мовних засобів у дітей дошкільного віку під впливом соціальних норм і гендерних стереотипів поведінки (Ушакова, 2006), фіксують статеві відмінності у виконанні мовних 
завдань на основі різних семантичних категорій (Soriano, Fumagalli, Shalom, Barreyro \& Martínez-Cuitiño, 2016), простежують вплив статі на вербальну поведінку респондентів похилого віку (Бондарь \& Гордиенко-Митрофанова, 2017).

3 проникненням у науковий простір когнітивно-дискурсивних засад, розробка гендерного дисплею рухається у напрямку концептуального аналізу й категоризації дійсності (Бєссонова, 2003; Ожгихина, 2006), конструювання гендерної ідентичності в різних типах дискурсу (Козачишина, 2003; Марчишина, 2015; Маслова, 2009). Науковому розгляду підлягає продукт мовленнєвомисленнєвої й психічної діяльності автора. Лімітована гендерними межами, стать письменника імплікується у створюваний текст, породжуючи «жіночий» та «чоловічий стилі». Ця проблематика знаходить розв'язання у вивченні психолінгвістичних аспектів перекладу (Засєкін, 2012), виявленні й реконструкції авторської особистості (Белянин, 2008).

Дослідження базуються переважно на матеріалі публіцистичних й художніх текстів. Однак, існуючі наукові доробки художнього дискурсу мають фрагментарний характер i повністю не простежують гендерні закономірності, адже фокусуються або на гендерному стилі автора, або враховують лише гендерні особливості персонажного мовлення. Вважаємо, що гендерний аналіз тексту повинен проводитись 3 точки зору співвідношення й взаємодії в літературному творі реального й фікціонального текстоутворювальних суб'єктів: автора й створеного ним художнього образу. 3 одного боку, персонаж художнього твору має певну незалежність, з іншого, автор створює художній образ 3 урахуванням свого особистого світосприйняття, через свої особисті характеристики, стать, зокрема. Все це і становить актуальність даної наукової студії.

Метою статті є виявлення специфічних ознак персонажного мовлення крізь призму гендерної ідентичності автора.

Досягнення поставленої мети передбачає вирішення таких завдань: 1) проаналізувати теоретичні засади гендерно зумовленої комунікативної поведінки; 2) визначити та кваліфікувати авторські інтенції в процесі трансляції персонажного мовлення 3 позицій гендерного підходу; 3) встановити та диференціювати специфічні 
ознаки, що ідентифікують справжню приналежність автора до тієї чи іншої статі.

Емпіричним матеріалом обрано масив текстів англомовного любовного роману авторів-жінок (Graham, 2005; Merritt, 2001; Mortimer, 1993; Roberts, 2002; Woods, 2000) і авторів-чоловіків під жіночим псевдонімом (Gordon, 1990; Greenwood, 2002; Ker, 2003, 2004; Sanderson, 2008; Williams, 1990). Будучи віднесеною до масової комунікації (Філоненко, 2011) дамська проза може досліджуватись і з точки зору розкриття тенденцій соціальної дійсності, і для виявлення певних характеристик джерела, що відображаються в текстах (Дридзе \& Леонтьев, 1976).

\section{Методи та методики дослідження}

Базовою інтегративною методикою дослідження визначено дискурс-аналіз. Саме дискурсивний чинник установлює взаємозв'язок традиційного лінгвістичного аналізу тексту 3 проеціюванням на елементи його змістовної та композиційномовленнєвої організації психологічних, соціально-культурних, прагматичних та інших факторів.

Хоча дискурс $є$ одним 3 найбільш складних і суперечливих термінів сучасної лінгвістики, у рамках психолінгвістичної теорії він постає сукупністю розумової та мовленнєвої діяльності, результатом якої $є$ певна лінгвістична структура - текст. Такий синтез процесу та результату відбувається на тлі соціокультурного контексту та має власне лінгвальний та екстралінгвальний плани (Красных, 2001). Тобто дискурс, як динамічне комунікативне явище, що розгортається в часі (дискурс як процес) структурується згідно 3 певними екстралінгвальними (психологічними, соціальними, культурними тощо) чинниками, що, у свою чергу, впливає на його власне лінгвальну форму - текст (дискурс як результат). Відповідно до цього можна стверджувати, що зміни, які відбуватимуться в соціокультурному контексті, повинні відображатися у вербальному оформленні дискурсу, у мовних засобах, що використовуються.

Англомовний художній дискурс має певні особливості, які докорінно відрізняють його від інших типів дискурсу. Насамперед, це цілеспрямована вторинність (вигаданість) художнього дискурсу 
відносно первинних жанрів мовлення (Красных, 2003). Слід однак зазначити, що, проходячи крізь уяву автора, художнє повідомлення $\epsilon$ «носієм» відбитої в художній комунікації реальної дійсності. В цьому випадку когнітивна й емоційна структурація вторинного тексту підпорядковується авторській свідомості.

Особистість письменника виявляється в прозовому творі і в ідейному оформленні, і на рівні мовної реалізації:

«Зміст тексту мислиться як результат об'єктиваиії психологічного стану автора, його інтересів, соціального статусу, його уявлень про ситуації спілкування $і$ про читача засобами мови» (Бехта, 2004: 63).

Доцільно зауважити, що, за словами М. Рюткенен (2000), письменник не може позбавитись свого соціального середовища, своєї історії, свого виховання i, врешті-решт, своєї статі. Все це відображається у художньому творі в явищі гендерної стилізації (Пермякова, 2007).

Автори протилежної статі мають різний досвід та передають його різними засобами, відрізняються стилем викладення художнього матеріалу та ступенем емоційності (Погребная, 2006). На думку французького теоретика-психоаналітика Е. Сиксу, у жінок $є$ виключна можливість виразити себе на письмі за допомогою жіночного стилю (Cixous, 1986). Тому у вербальному наповненні художнього тексту інтенція автора реалізується крізь призму соціокультурних чинників, ґендера зокрема. Експлікуючи свої особисті психологічні, ціннісні, соціальні орієнтири, автор не тільки впливає на формування певних стереотипів у читача, а й творить свої.

Оскільки мовлення персонажа генерується не самим «мовцем», а автором, у художньому тексті йдеться про реальний текстоутворювальний суб'єкт, який уособлює автора та фікціональний текстоутворювальний суб'єкт, що втілюється в художньому образі персонажа. На думку О.Л. Антинескул (2001), адекватне визначення цьому дворівневому утворенню дає термін мовна особистість, що позначає

«сукупність здібностей та характеристик людини, щзо зумовлюють створення та сприйняття нею мовленнєвих творів (текстів)» (Караулов, 1987: 3). 
Аналізуючи ідеї В.В. Виноградова і Ю.Н. Караулова, дослідниця вважає, що позбавлене індивідуальності «parole» реалізується в художньому творі у вигляді персоніфікованого мовлення, що продукується мовною особистістю. Таким чином, якщо за вихідну величину береться мовна особистість, перед ученим виникають два шляхи: крізь ємну категорію автора та художнього образу.

Ураховуючи все вищезазначене, аналізувати особливості гендерно зумовленої комунікативної поведінки будемо в площинах авторів та персонажів. На першому етапі дослідження проводиться контент-аналіз вибірки, який полягає в кількісному описі змісту комунікації та спрямований на категоризацію якісних текстових даних. Залучення елементів інтент-аналізу спрямовано на те, щоб на базі вербального матеріалу схарактеризувати супутні мовленню психічні процеси та стани.

\section{Результати та дискусії}

Наукові студії комунікативної поведінки різностатевих індивідів на сучасному етапі не виявили вкрай суттєвих відмінностей. Зокрема, було встановлено, що на перебіг комунікації впливає цілий ряд позамовних чинників, таких як рівень освіти мовців, їхній соціальний статус, сфера спілкування тощо (Агеєва, 2004). Отже, в дослідженні йдеться не про різні мовні варіанти, а лише про гендерно зумовлені комунікативні ознаки, що є більш характерними для комунікативної поведінки чоловіків і жінок. Вважаємо, що гендер не може не впливати на комунікативні процеси, адже поведінка людини в ході спілкування, окрім зазначених чинників, регулюється й гендерними стереотипами, й комунікативними нормами, й традиціями, що відповідають соціальній гендерній ролі.

Розглядаючи мовленнєву поведінку в гендерному аспекті, можна виділити «чоловічий» або «жіночий» образ мовленнєвих дій, що складає гендерний комунікативний стиль -

«домінуючу манеру спілкування, що проявляється в більшості комунікативних ситуаиій» (Стернин, 2003: 97).

Основною рисою «жіночого» комунікативного стилю стереотипно вважається орієнтування на співробітництво та 
установлення контакту зі співрозмовником, тоді як «чоловіча» комунікативна поведінка спрямована на конфлікт, змагальну та домінуючу взаємодію (Maltz \& Borker, 1982). Таким чином, головними принципами «чоловічої» та «жіночої» комунікативної інтеракції стають відповідно кооперація та суперництво (Tannen, 1990).

Партнерський характер «жіночої» комунікації створюється за рахунок використання цілого спектра мовних засобів. Уважається, що жінки частіше за чоловіків використовують у своєму мовленні вставні слова й вирази (hedges). Конструкції на зразок I think, I suppose, sort of, probably, possibly, certainly, you see, you know дозволяють не тільки підтримати розмову, але й висловити свою точку зору без стримування ініціативи іншого комуніканта (Lakoff, 1973). Згідно зі стереотипними уявленнями, мовленню жінок приписується схильність до пом'якшення категоричності висловлювань за рахунок вживання структури з let's go, going to, а також модальних дієслів у поєднанні 3 виявленням невпевненості could, should, may, might (Coates \& Cameron, 1989: 223).

«Жіночій» вербальній поведінці притаманні й ознаки «дитячого» мовлення (Кеу, 1975), використання великої кількості компліментів та похвальних висловлювань на адресу співрозмовників, вибачень та перепрошень, навіть без наявності провини (Holmes, 1995).Усі ці стереотипні риси «жіночої» комунікації дозволяють гармонізувати атмосферу спілкування й зменшити дистанцію між учасниками діалогу.

Для більшості чоловіків спілкування - це конкуренція, засіб створення й підтримки ієрархії (статусу) шляхом демонстрації своєї інформованості, впевненості, сили (Гриценко, 2005). Домінуючі риси «чоловічому» комунікативному стилю надають директивні конструкції. Згідно з експериментальними даними, представники чоловічої статі тяжіють до вживання категоричних форм наказового способу, часто віддають команди, супроводжуючи їх констатацією своїх бажань та намірів (Coates, 1986).

Розв'язування конфронтації, що стереотипно співвідноситься iз чоловічою статтю, відбувається за рахунок переривання спілкування. Доведено, що в одностатевій комунікації чоловіки майже не перебивають співрозмовника, тоді як у бесіді 3 жінками використовують перебивання, не даючи можливості здійснити 
висловлювання. Наведення переконливих аргументів, часті запитання, розбіжності в поглядах й сперечання 3 партнером 3 комунікації також є особливостями конфліктної вербальної поведінки, характерної для чоловіків (Holmes, 1995).

Важливу роль у комунікативній поведінці чоловіків і жінок відіграють їхні емотивні властивості. Стереотипні погляди на міжгендерну комунікацію базуються на ствердженні про переважну емоційність жінок. «Чоловічий» текст бідніший за жіночий в емоційному плані: у ньому менше описів і згадувань емоцій, емоційна лексика бідна й одноманітна (Земская, 1993). Надмірне використання підсилювальних слів і емфаз (terribly, horribly, awfully, so, such), вживання прикметників, що мають особливий конотативний відтінок захоплення, подиву та інших емоційних станів (charming, adorable, sweet, lovely, divine), наявність великої кількості вигуків (Oh dear, Good heavens, Gosh, Oh Lord, Gracious), гіперболізоване мовлення (Romaine, 1999: 100) є типовими засобами жіночої експресії.

Особливе місце у вербальній поведінці чоловічої статі займає некодифікована лексика. Чоловіки більшою мірою використовують вульгаризми, інвективи, жаргонізми та сленг (Jespersen, 1922), що характеризує їх як схильних до авторитарності та агресивності в комунікації. «Жіноча» комунікативна поведінка характеризується «гіперкоректністю», що досягається за рахунок великої кількості ввічливих форм, евфемізмів (Brown \& Levinson, 1987).

Враховуючи мету розвідки, наукову увагу скеровуємо на особливості існування лексики, що має асоціальну природу й заборонена до вжитку у переважній більшості лінгвокультур. Засадницьким принципом дослідження $є$ розгляд розбіжностей в чоловічому й жіночому мовленні не тільки як чинника, що відбиває гендерну приналежність автора, але i як головного параметра диференціації мовних засобів при імітуванні автором мовлення протилежної статі. Згідно з сучасними студіями у криміналістичній сфері саме нецензурна лексика відноситься до тих глибинних ознак мовлення, що важко сфальсифікувати (Гомон, 1990).

Слід зазначити, що заборона на певні слововживання $\epsilon$ національно-специфічним явищем і зумовлена низкою історичних, соціальних та культурних чинників, релігією та політикою, нормами моралі та етики (Селіванова, 2010). Для англомовного суспільства 
сфера табу включає: релігійні і сакральні явища та поняття (God, Jesus Christ, hell, devil), задоволення хіті (a blow job, to fuck, to make out, to shag), видалення продуктів життєдіяльності (to pee, to vomit, shit), людське тіло (ass, cock, dick, nipples), хвороби та смерть (cancer, death) (Allan \& Burridge, 2006). Цензурі підлягають також інсинуації (kike, nigger), лайки й лихослів'я (damn, bloody, bitch) (Claire, 1998).

У ході дослідження було виявлено не тільки низькі кількісні дані існування аналізованої лексики в художніх творах авторівчоловіків, але й принципові якісні відмінності ii використання, порівняно з авторами-жінками. Загальна кількість табу в текстах, написаних чоловіками, становить 165 лексичних одиниць, що майже в чотири рази менше, ніж у жіночих авторів - 633 одиниці відповідно:

Розподілення лексикону між персонажами обох статей у авторів-чоловіків не має істотних розбіжностей і становить 85/80 3 невеликою перевагою на користь жіночих протагоністів. Авторижінки навпаки, відтворюючи маскулінну комунікативну поведінку, вживають 498 слів 3 табуйованим значенням, тоді як жіноча комунікація характеризується наявністю лише 135 лексем-табу:

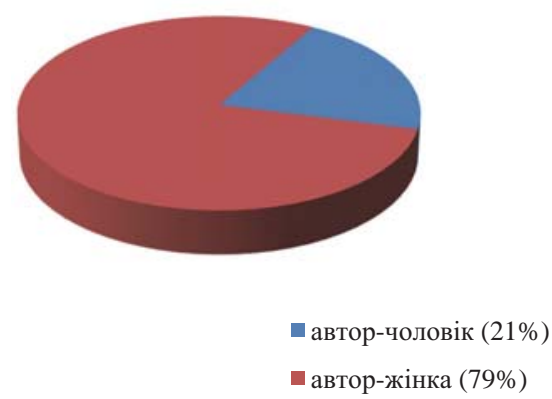

Рис. 1. Кількісні показники вживання табуйованої лексики у творах авторів-чоловіків порівняно з авторами-жінками

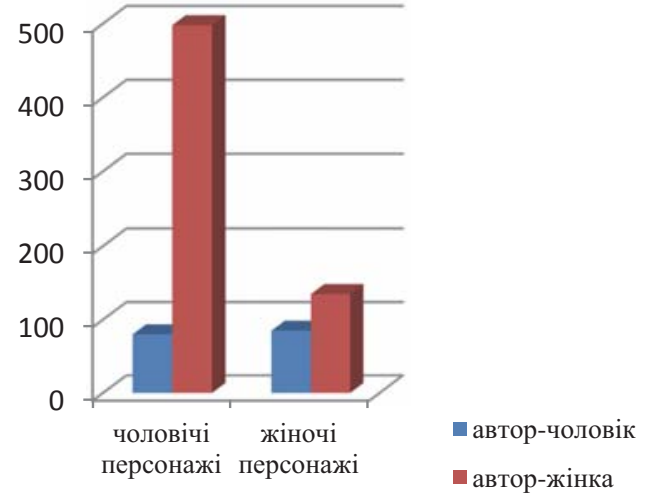

Рис. 2. Розподілення табуйованої лексики між чоловічими $i$ жіночими персонажами у творах різностатевих авторів

Однак найбільшу дослідницьку зацікавленість викликає диференціація аналізованої лексики між персонажами обох статей, 
iii якісний аналіз задля виявлення прагматичних інтенцій автора в процесі відтворення жіночої та чоловічої комунікативної поведінки:

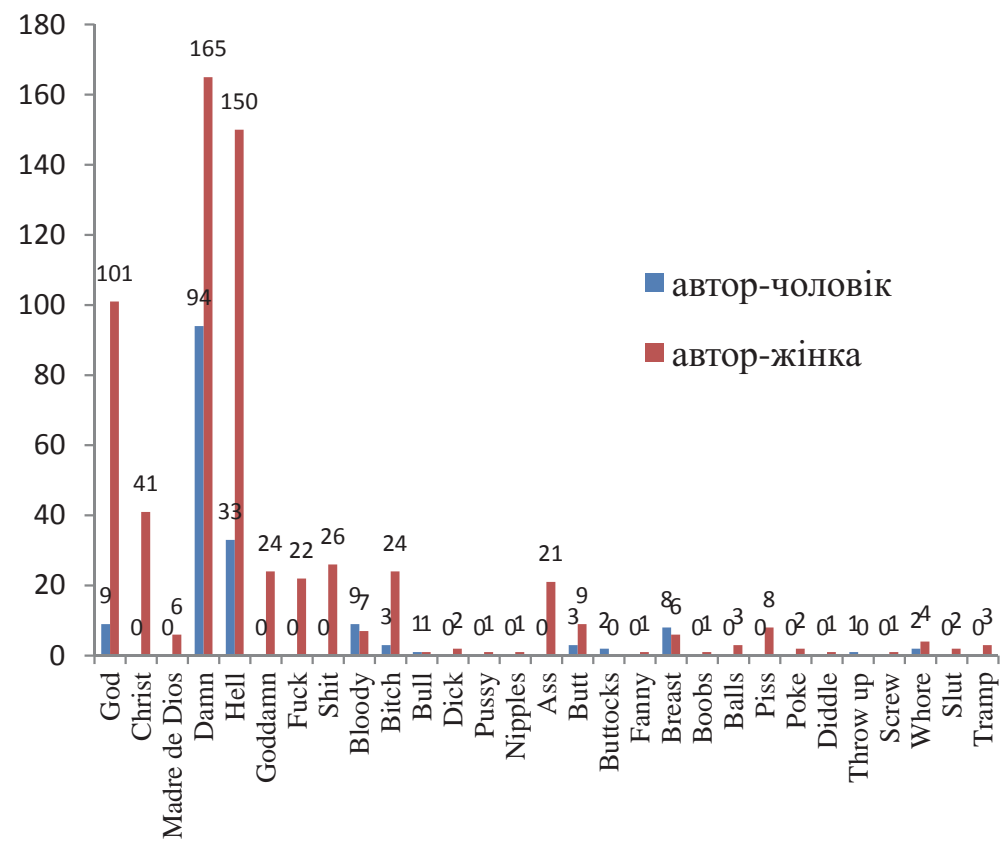

Рис. 3. Диференціаиія табуйованої лексики у творах різностатевих авторів

Отримані чисельні показники у творах авторів-жінок підтримують стереотип про чоловіче лідерство в сфері використання «імені Бога всує», сварок, лайок, вільного вживання вульгаризмів. Володіння відповідним вокабуляром у багатьох лінгвокультурах, зокрема англомовній, характерно для соціально домінуючих індивідів, i, навпаки, для підлеглих їм осіб це слововживання заборонено або сильно обмежено.

Серед усієї кількості мовних табу комунікація чоловічих персонажів тяжіє до більшого вживання релігійної лексики у профанному змісті. Спостерігається використання термінології в побутовому сенсі поза релігійного контексту переважно в емоційно навантажених ситуаціях. Лексика такого роду не має явно вираженого агресивного або презирливого ставлення до релігії й віри й вживається головним чином у вигукових висловлюваннях, наприклад: 
"Thank God I caught you!' gasped a breathless voice behind her. 'I thought I was going to be too late.' Cyn had been in the act of quietly slipping away from the front entrance of the hotel, but she turned sharply at the first sound of Wolf Thornton's voice» (Mortimer, 1993: 58).

Будучи явними домінантами в експлікації вербальної агресії, чоловічі персонажі майже в чотири рази частіше, ніж жіночі використовують лексеми damn i hell у своїй комунікації. Слід зазначити, що агресія спрямована на ситуацію в цілому і створює негативну атмосферу конфронтації, наприклад:

"Cam began to pace, long, furious strides up and down the narrow dock. "What, do they think he was crazy for taking the kid on? Hell, he was crazy for taking any of us on, but what does that have to do with an accident?» (Roberts, 2002: 25).

В маскулінній вербальній поведінці спостерігається тенденція до вживання damn i hell як інтенсифікаторів, які, крім семи інтенсивності, відзначені конотацією непристойності, що збільшує прагматичну «вагу» висловлювання й більш чітко формує уявлення про оцінний знак емоції, що передається, наприклад:

«Cyn had no intention of betraying Rebecca, and shrugged dismissively. 'Do you love Rebecca Harcourt? He drew in a harsh breath. 'What the hell do my feelings for Rebecca have to do with you?» (Mortimer, 1993: 33).

Ще один сегмент забороненого лексикону становлять лихослів'я й лайки. Маючи пейоративну експресію несхвалення, презирства, висловлювання, лексеми fuck, shit, bitch, bloody, bull містять явну негативну оцінку, що суспільно усвідомлюється й сприймається адресатом як образлива. Уживаються такі вирази переважно в ситуації чоловічого спілкування з метою дискредитації інвектума, наприклад:

"To her. I'll go right now. I'll get my stuff and I'm gone. And if you think you can stop me, you're full of shit» (Roberts, 2002: 36).

Наявність інвектив whore та tramp у вербальній поведінці чоловічих дійових осіб спрямована на жіночі персонажі при виявленні зневажливого ставлення. Так, наприклад, невдоволений зовнішнім виглядом своєї знайомої, головний герой презирливо порівнює іiі із блудницею: 
"In the act of offering the policeman a cigar, Rafael flicked her a stabbing glance from deep-set dark eyes, treacherous as black ice, and murmured lazily in aside, 'Pull your skirt down and cover yourself ... you look like a whore» (Graham, 2005: 14).

Належачи до емоційно підвищеної, афективної сфери, груба лайка, виконуючи експресивну функцію, підвищує «градус» емоційності висловлювання в конкретній ситуації, наприклад:

- "They don't expect him to come out of it.'

- 'That's bull shit. He's strong as an ox.» (Roberts, 2002: 16).

Матеріальний, земний початок представлено у вербальній поведенці чоловічих персонажів у вигляді назв різних людських органів i дій, що мають, у першу чергу, відношення до дітонародження й видалення відходів життєдіяльності. Ігноруючи норми моралі й етики, маскулінні персонажі використовують у своїй комунікації табуйовані лексеми: ass, butt, piss, breast, balls, dick, poke, pussy, diddle, boobs, nipples 3 метою навмисного огрубіння мовлення. Це сприяє створенню образу сучасного домінуючого чоловіка.

У ситуації одностатевої комунікації спостерігається дружнє кепкування. Застосовуючи табуйовану лексему butt, персонажчоловік підтверджує свою групову приналежність:

- "How's the crab business looking?'

- 'It'll do,' Ethan said shortly. Cam lifted his brows at the tone.

- 'What, did one crawl out of the pot early and up your butt?"

(Roberts, 2002: 128).

Детальний розгляд аналізованого лексикону жіночих персонажів англомовного любовного роману авторів-жінок виявив значно меншу наявність табуйованих слів i виразів порівняно із кількістю такого роду лексем у висловлюваннях персонажів-чоловіків.

При вживанні релігійної лексики у висловлюваннях фемінних дійових осіб перевага надається експлетивним вигукам. За допомогою такого роду лексики жіночі персонажі проявляють різноманітний спектр емоційних станів: від подиву до гніву. Відзначимо, що в жіночих репліках, які містять вигуки, превалює релігійне табу God як засіб виявлення полегшення, наприклад: 
"Thank God the alligator didn't get me,» she murmured, with heartfelt gratitude that she had been spared for a future of such unsurpassed ecstasy»(Graham, 2005: 219).

Вербальна поведінка жіночих дійових осіб в атмосфері напруженості й конфронтації конструюється такими мовленнєвими засобами агресіï, як damn й hell. Згідно з існуючими стереотипами, жінки знаходяться у стані підлеглості. Чоловіче домінування нав'язує жінкам покору, стримування своїх негативних емоцій. Будучи домінантною ознакою вербальної поведінки чоловіків, лайлива лексика все ж таки знаходить своє застосування і в репліках персонажів-жінок як ємний засіб втілення негативних почуттів, наприклад:

«Not me! Melanie thought. I'm not taking any orders from Eli Forrester and I just wish he'd try to give me one so I could lambaste the hell out of him!» (Merritt, 2001: 78).

Як і в чоловічих персонажів, висловлювання персонажів-жінок не містять різко богохульного слововживання.

Використання табуйованих слів, пов'язаних зі сферою «людського низу» (breast, butt, fanny, piss, screw) має симптоматичне включення в комунікацію жіночих персонажів, носить одиничний характер i вживається в основному в емоційно забарвлених ситуаціях, по-перше, 3 катартичною метою й, по-друге, для досягнення певного прагматичного ефекту. Задля підвищення емоційності висловлювання героїні автор уводить у іiі репліку вульгаризм piss off, досягаючи тим самим прагматичного впливу на адресата-чоловіка, який розуміє, що жінка не просто невдоволена, а вкрай роздратована:

«Do I looked pissed off?' she asked coolly» (Roberts, 2002: 324).

Вульгаризми bloody та fuck також використовуються для трансляції емоційного стану. I, якщо bloody передає негативно забарвлені хвилювання головної героїні, то табуйована одиниця fuck вживається задля підсилення сексуального напруження, наприклад:

«Stuff you bloody feelings!' Georgie gasped, suddenly swinging away from him, her voice embarrassingly choked» (Graham, 2005: 32); «Martine wrapped a hand around him like a clamp. 'Tell to go to hell and fuck me» (Roberts, 2002: 5). 
Цікаво, що агресивні інвективи bitch, whore, slut, tramp при вживанні у висловлюваннях персонажів-жінок спрямовані не на девалоризацію опонента жіночої статі, а використовуються як рефлексії чоловічої думки про жінок. Так, наприклад, у ситуації, коли головна героїня розгублена, скривджена зневажливим ставленням до неї іiі коханого:

"Georgie murmured hopefully, taking up the challenge with a vengeance. 'If he chose to think that she was a drunk as well as a slut, he was quite free to do so» (Graham, 2005: 56).

Більшу частину табуйованої лексики персонажів обох статей у авторів-чоловіків займають профанізми, що містять інвективи God, damn, hell. Однак, якщо в авторів-жінок у репліках фемінінних персонажів превалює релігійне табу God, то у письменників-чоловіків на перше місце виходять табуйовані лексеми damn i hell.

Ці слова використовуються автором, насамперед, 3 метою полегшення емоційної напруги, як ємний мовленнєвий засіб для виходу негативних емоцій. Треба зазначити, що у висловлюваннях персонажів-жінок слова damn i hell мають високий образливий потенціал, тим самим налаштовуючи комунікативну поведінку в напрямку вербальної агресії, формуючи атмосферу конфронтації, домінування. Вербальна агресія скерована в основному на чоловічого персонажа, наприклад:

"Fiona stopped her pacing with a sudden, exultant laugh. She refused to refill her wine glass and raised it triumphantly. 'And to hell with you, Dare Fraser,' she cried! 'Too late!» (Gordon, 1990: 26).

Слід зазначити, що жіночі персонажі вживають лексеми damn й hell у своїй комунікації і без суб'єктивної спрямованості. У цьому випадку лексика такого роду не має яскраво вираженого образливого характеру. Так, украй роздратована й розлючена поведінкою чоловічого персонажа, який не тільки намагається переграти іiі в бізнесі, але й зневажливо ставиться до неї як до професіонала, головна героїня рішуче наполягає:

"I don't personally give a damn what you're through with,' she flared, shaking herself as if simple movement could erase the feel of his hand against her neck» (Gordon, 1990: 16). 
У маскулінній вербальній поведінці лексеми damn i hell виконують переважно функцію інтенсифікації. У поєднанні 3 іменниками, прикметниками й прислівниками вони не тільки підсилюють їхній оцінний потенціал, але й беруть участь у формуванні прагматичного ефекту, емоційно «заряджають» висловлювання, наприклад:

«Dammit! Shamus shouted, his face turning purple. 'I worked a damned year to get that contract» (Greenwood, 2002: 102).

У жіночій комунікації в якості інтенсифікатора превалює лексема damn. Необхідно зауважити, що використовується вона переважно як засіб втілення негативної чуттєвої сфери, здійснюючи відповідний прагматичний вплив на реципієнта, наприклад:

«Well, you can damned well wait out here,' Fiona retorted, turning away as quick as possible» (Gordon, 1990: 114).

Зниження релігійного образу шляхом постійного вживання табуйованої лексеми God не є характерним ні для фемінної, ні для маскулінної комунікації. Експлетивні вирази, що містять у своєму складі це слово, використовуються автором-чоловіком в основному в ситуаціях, що описують почуття полегшення й потрясіння, наприклад:

"My God, I've found you at last,' he whispered, holding her gaze with those grey eyes that could be as cold as the Arctic sea, or blaze like the sun off ice» (Ker, 2003: 4).

Аналіз вульгаризмів bloody, bitch, whore, свідчить про їхній малий вміст у вербальній поведінці персонажів обох статей. Зазнають змін і якісні характеристики такого роду табуйованого слововживання. Необхідно підкреслити, що у фемінній комунікації інвективи bitch та whore спостерігаються в поодиноких випадках 3 метою зачепити, скривдити опонента. Вербальна агресія скерована на адресата жіночої статі, наприклад:

«Oh, sure,' Fiona sneered. 'And look who's the majority shareholderthat bitch of a woman from Chile, or Argentina or wherever. The one who hated me on first sight, who's done nothing but go out of her way to cause me problems. And you suggest he didn't know?» (Gordon, 1990: 109). 
Мовленнєва поведінка комунікантів в контексті тендерної...

Інтенсифікація емоційного посилання через вживання вульгаризму bloody простежується в репліках персонажів обох статей. Треба зазначити, що емоції такого роду належать негативному просторові. Саркастичне зауваження в поєднанні 3 інтенсифікатором-вульгаризмом посилює емоції люті й гніву, наприклад:

"The last thing my 'best' neighbor would do is help me organize a dog-training school next to his precious bloody sheep!» (Gordon, 1990: 97).

Підкреслимо, що, уникаючи прямого вживання обсценної сварки, автор-чоловік використовує й пейоративну лексику переважно в жіночій комунікації. За допомогою пейоративів формується негативна оцінка, передається несхвалення, осудження, презирство, наприклад:

"As a matter of fact, you've just proved that you're the heartless bastard I always knew you were» (Ker, 2003: 18).

Матеріальний, земний початок не знаходить вираження у висловлюваннях чоловічих персонажів. У жіночій комунікації спостерігаємо таку табуйовану лексику: breasts, buttocks, butt, throw up, що характеризує зміну нормативних приписів до порушення етичних принципів. Так, наприклад, невдоволена увагою свого коханого до іншої жінки, головна героїня навмисно звертає його увагу на певні недоліки в зовнішності опонентки, вказуючи на певні частини їі тіла:

«Oh. How cultured you are. Those breasts aren't real, you know» (Ker, 2004: 92).

\section{Висновки}

Проведений аналіз текстів англомовного любовного роману автора-жінки 3 його андроцентричними установками дозволив підтвердити той факт, що існуючі стереотипи соціальної поведінки гендерно закріплені за жіночою і чоловічою половиною англомовного соціуму й знаходять своє відображення у вербальній поведінці жіночих і чоловічих персонажів. Наявні гендерні норми 
формують певні комунікативні правила, диктують вибір мовних засобів для створення вербального образу ідеального чоловіка i жінки: нехтування моральними приписами й дотримання існуючих комунікативних норм відповідно. У ході дослідження в маскулінних висловлюваннях було виявлено превалювання табуйованого лексикону, спрямованого на конфлікт, змагальну й домінуючу взаємодію. Тоді як вербальна поведінка персонажів жіночої статі характеризується не тільки значно меншим використанням забороненої лексики, але й спрямована на співробітництво й кооперацію за рахунок пом'якшення категоричності висловлювань.

Гендерна диференціація вживання табуйованого лексикону в аналізованих художніх творах авторів-чоловіків суперечить загальноприйнятому стереотипу використання табу переважно чоловіками. На нашу думку, такий результат пов'язаний з явищем гендерної стилізації, що являє собою імітацію стереотипних особливостей мовлення особи протилежної статі.

Слід зазначити, що стильова імітація відбувається у двох напрямках. Автор стилізує висловлювання персонажів відповідно до певного гендерного комунікативного стилю. В аналізованих романах авторів-жінок значне превалювання табуйованої лексики $\epsilon$ характерним для маскулінної вербальної поведінки, що прямо відбиває існуючі гендерні стереотипи вживання такого роду лексикону. Жіночі автори, прагнучи передати такі якісні чоловічі характеристики, як гнів, агресію, нетерпимість, створюють стереотипні чоловічі образи за допомогою відповідної лексики.

Автори-чоловіки, які працюють під жіночими псевдонімами, свідомо відтворюють стереотипні особливості мовлення протилежної статі, стилізуючи тексти під жіночу манеру письма. Це виявляється в зменшенні кількості табуйованих лексичних одиниць у комунікації персонажів обох статей. Однак ми вважаємо, що, використовуючи жіночий стиль письма, автор не втрачає своєї гендерної ідентичності. Отже, поряд 3 імітованими рисами, у текстах виявляються й ідентифікуючі ознаки, що відбивають справжню гендерну приналежність автора. Такого роду ознаки можна простежити у превалюванні табуйованих лексем damn та hell в комунікації різностатевих дійових осіб у текстах авторівчоловіків, на відміну від вербальної поведінки чоловічих та жіночих персонажів у текстах авторів-жінок. 
Перспективою подальшого студіювання гендерно зумовленої комунікативної поведінки вбачаємо у дослідженні явища евфемізації в макродіахронічному зрізі. Дослідницький інтерес становить теза про регресивний характер чоловічого домінування в комунікації, послаблення виявів вербальної агресії, суперництва та конфронтації при спілкуванні, зважаючи на сучасні процеси маскулінізації жінки і фемінізації чоловіка.

\section{Література}

Агеєва, В.П. (Ред.). (2004). Основи теорії гендеру. Київ: «К.І.С.».

Антинескул, О.Л. (2001). Гендер как параметр текстообразования. Пермь: Перм. Ун-т.

Барышникова, Г.В. (2004). Гендерные различия эмоциональной компоненты во французской художественной коммуникации (на материале литературы XVII-XX веков). Дисс. канд. филол. наук. Волгоград.

Белянин, В.П. (2008). Авторский смысл эмоционально-отмеченного текста и проблема реконструкции личности автора. Теория и практика судебной экспертизы, 4 (12), 181-184.

Бехта, І.А. (2004). Дискурс наратора в англомовній прозі. (Монографія). Київ: Грамота.

Бєссонова, О.Л. (2003). Оцінний тезаурус англійської мови: когнітивний і гендерний аспекти. Дис. д-ра. філол. наук. Київ.

Бондарь, Ю., \& Гордиенко-Митрофанова, И. (2017). Влияние пола на вербальное поведение респондентов поздней зрелости при исследовании стимула «игривость». Психолінгвістика, 21 (1), 65-85.

Гомон, Т.В. (1990). Исследование документов с деформированной внутренней структурой. Дисс. канд. юрид. наук. Москва.

Горошко, Е.И. (1996). Особенности мужского и женского вербального поведения: психолингвистический анализ. Дисс. канд. филол. наук. Москва.

Горошко, Е.И. (2001). Языковое сознание: ассоциативная парадигма. Дисс. д-ра. филол. наук. Москва.

Гриценко, Е.С. (2005). Язык как средство конструирования гендера. Дисс. д-ра филол. наук. Нижний Новгород.

Дридзе, Т.М., \& Леонтьев, А.А. (1976). Смысловое восприятие речевого сообщения: в условиях массовой коммуникации. Москва: Наука.

Засєкін, С.В. (2012). Психолінгвістичні універсалії перекладу художнього тексту. (Монографія). Луцьк: Волинський університет ім. Лесі Українки.

Земская, Е.А. (1993). Особенности мужской и женской речи. Е.А. Земская \& Д.Н. Шмелев (Ред.), Русский язык и его функционирование. Москва: Наука.

Иванова, Е.С. (2011). Вербализация эмоций: возрастные и гендерные различия. Известия Уральского государственного университета, 4 (95), 180-188.

Караулов, Ю.Н. (1987). Русский язык и языковая личность. Москва: Наука.

Кирилина, А.В. (1998). «Мужественность» и «женственность» с точки зрения лингвиста. Женщина в российском обществе, 2, 21-27. 
Клецина, И.С. (2009). Психология гендерных отношений: теория и практика. Санкт-Петербург: Алетейа.

Козачишина, О.Л. (2003). Лінгвістичні прояви гендерних характеристик англомовних художніх текстів (на матеріалі американської прози XX сторіччя). Дис. канд. філол. наук. Київ.

Красных, В.В. (2001). Основы психолингвистики и теории коммуникации. Москва: Гнозис.

Красных, В.В. (2003). «Свой» среди «чужих»: миф или реальность? Москва: Гнозис.

Крейдлин, Г.Е. (2005). Мужчины и женщчины в невербальной коммуникации. Москва: Языки славянской культуры.

Кубрякова, Е.С. (1995). Эволюция лингвистических идей во второй половине XX века (опыт парадигмального анализа). Ю.С. Степанов (Ред.), Язык и наука конца $X X$ века (с. 144-238). Москва: Изд-во Российск. гос. гуманит. ун-та.

Кузнецов, М.А. (2015). Гендерные особенности эмоциональной и автобиографической памяти. Право $і$ безпека, 1 (56), 102-108.

Марчишина, А.А. (2015). Поетика гендерної ідентичності в постмодерністському художньому дискурсі. Науковий вісник ДДПУ ім. І. Франка, 4, 102-106.

Маслова, Ю.П. (2009). Моделі гендерної ідентичності жінки на сторінках друкованих ЗМІ. Наукові пращі Кам>янещьь-Подільського національного університету ім. Івана Огієнка, 20, 400-403.

Ожгихина, Е.С. (2006). Концептуальный анализ рекламного текста с позиции гендера (на материале английского языка). Дисс. канд. филол. наук. Уфа.

Пермякова, О.В. (2007). Явление гендерной стилизации в современной женской литературе (на материале французского и русского языков). Дисс. канд. филол. наук. Пермь.

Погребная, В.Л. (2006). Мир русского женского романа (1860-1880 гг.). Запорожье: ЗНУ.

Рюткенен, М. (2000). Гендер и литература: проблема «женского письма» и «женского чтения». Филологические науки, 3, 5-17.

Селіванова, О.О. (2010). Лінгвістична енцииклопедія. Полтава: Довкілля.

Стернин, И.А. (2003). К разработке модели контрастивного описания национального коммуникативного поведения. В.И. Карасик \& Н.А. Красавский (Ред.), Аксиологическая лингвистика: проблемь коммуникативного поведения. Волгоград: Перемена.

Ушакова, М.Ю. (2006). Гендерные особенности речи детей дошкольного возраста. Дисс. канд. психол. наук. Иркутск.

Філоненко, С.О. (2011). Масова література в Украӥні: дискурс/гендер/жанр. (Монография). Донецьк: ЛАНДОН-XXI.

Allan, K., \& Burridge, K. (2006). Forbidden Words. Taboo and censoring in English. Cambridge: Cambridge University Press. https://doi.org/10.1017/ CBO9780511617881

Bem, S.L. (1993). The lenses of gender: Transforming the debate on sexual inequality. New Haven: Yale University Press.

Brown, P., \& Levinson, S. (1987). Politeness: Some universals in language use. Cambridge: Cambridge University Press. https://doi.org/10.1017/ CBO9780511813085

Cixous, H. (1986). The Newly Born Woman. Manchester: Manchester University Press. 
Claire, E. (1998). Dangerous English 2000. Los Angeles: Delta Publishing Company. Coates, J., \& Cameron, D. (1989). Women in Their Speech Communities. New York: Longman.

Coates, J. (1986). Women, men and language. New York: Longman.

Dovidio, J., Heltman, K., Brown, C., Ellyson, S., \& Keating, C. (1988). Power displays between women and men in discussions of gender-linked tasks: a multichannel study. Journal of Personality and Social Psychology, 55 (4), 580 587. https://doi.org/10.1037/0022-3514.55.4.580

Gordon, V. (1990). Love Thy Neighbour. London: Harlequin Books.

Graham, L. (2005). Crime of passion. Richmond: Mills and Boon.

Greenwood, L. (2002). Family Merger. New York: Silhouette Books.

Holmes, J. (1995). Women, men and politeness. New York: Longman.

Jespersen, O. (1922). Language, its Nature and Origin. London: Unwin Brothers.

Ker, M. (2003). Ruthless Husband, Convenient Wife. London: Harlequin Books.

Ker, M. (2004). The Millionaire Boss's Mistress. New York: Harlequin Books.

Key, M.R. (1975). Male/Female Language. New Jersey: Lawrence Eribaum.

Lakoff, R. (1973). Language and Women's Place. Language in Society, 2 (1), 45-80. https://doi.org/10.1017/S0047404500000051

Maltz, D., \& Borker, R. (1982). A Cultural approach to male-female miscommunication. In J.J. Gumperz (Ed.), Language and social identity (pp. 196-216). New York: Cambridge University Press. https://doi.org/10.1017/CBO9780511620836.013

Merritt, J. (2001). The Kincaid Bride. Richmond: Silhouette Books.

Mortimer, C. (1993). Return Engagement. Richmond: Mills and Boon.

Roberts, N. (2002). Sea Swept. London: Piatkus.

Romaine, S. (1999). Communicating Gender. London: Oxford University Press. https://doi.org/10.4324/9781410603852

Sanderson, G. (2008). Nurse Bride, Bayside Wedding. New York: Harlequin Books.

Soriano, F., Fumagalli, J., Shalom, D., Barreyro, J.P., \& Martínez-Cuitiño, M. (2016). Gender differences in semantic fluency patterns in children. East European Journal of Psycholinguistics, 3 (2), 92-102. doi: 10.5281/zenodo.267879

Steckler, N., \& Rosenthal, R. (1985). Sex differences in nonverbal and verbal communication with bosses, peers and subordinates. Journal of Applied Psychology, 70 (1), 157-163. https://doi.org/10.1037/0021-9010.70.1.157

Tannen, D. (1990). You just don't understand: Women and men in conversation. New York: William Morrow.

Tannen, D. (Eds.). (1993). Gender and conversational interaction. New York: Oxford University Press.

Williams, L. (1990). Spirits Willing. London: Harlequin Books.

Woods, S. (2000). The Print-Sized Secret. Richmond: Silhouette Books.

\section{References}

Aheieva, V.P. (Ed.). (2004). Osnovy teorii henderu [The basics of gender theory]. Kyiv: «K.I.S.» [in Ukrainian].

Antineskul, O.L. (2001). Gender kak parametr tekstoobrazovaniia [Gender as a parameter of text formation]. Perm: Permskii Universitet [in Russian].

Baryshnikova, G.V. (2004). Gendernye razlichiia emotsionalnogo komponenta vo frantsuzskoi khudozhestvennoi kommunikatsii (na materiale literatury XVII- 
$\mathrm{XX}$ vekov) [Gender differencies of emotional component in French literary communication (based on the XVII-XX century literature)]. Candidate's thesis. Volgograd [in Russian].

Belianin, V.P. (2008). Avtorskiy smysl emotsionalno-otmechennogo teksta i problema rekonstruktsii lichnosti avtora [The author's meaning in an emotionally marked text and the problem of the author's personality reconstruction]. Teoriia i praktika sudebnoi ekspertizy - Theory and practice of legal expertise, 4 (12), 181-184 [in Russian].

Bekhta, I.A. (2004). Dyskurs naratora v anhlomovnii prozi. [The narrator's discourse in the English language prose]. Kyiv: Hramota [in Ukrainian].

Biessonova, O.L. (2003). Otsinnyi tezaurus anhliiskoi movy: kohnityvnyi i gendernyi aspekty [Evaluative thesaurus of the English language: cognitive and gender aspects]. Doctor's thesis. Kyiv [in Ukrainian].

Bondar, J., \& Gordienko-Mitrofanova, I. (2017). Vliyanie pola na verbalnoe povedenie respondentov pozdney zrelosti pri issledovanii stimula «igrivost» [Gender influence on elderly respondents' verbal behavior while studying the stimulus «playfulness»]. Psykholinhvistyka - Psycholinguistics, 21 (1), 65-85 [in Russian].

Gomon, T.V. (1990). Issledovanie dokumentov s deformirovannoi vnutrennei strukturoi [The analysis of documents with a deformed structure]. Candidate's thesis. Moscow [in Russian].

Goroshko, E.I. (1996). Osobennosti muzhskogo i zhenskogo verbalnogo povedeniia: psikholingvisticheskii analiz [The peculiarities of male and female communicative behavior: psycholinguistic analysis]. Candidate's thesis. Moscow [in Russian].

Goroshko, E.I. (2001). Iazykovoe soznanie: assotsiativnaia paradigma [Language perception: associative paradigm]. Doctor's thesis. Moscow [in Russian].

Gritsenko, E.S. (2005). Iazyk kak sredstvo konstruirovaniia gendera [The language as a means of gender construction]. Doctor's thesis. Nizhni Novgorod [in Russian].

Dridze, T.M., \& Leontev, A.A. (1976). Smyslovoe vospriiatie rechevogo soobshcheniia: $v$ usloviiakh massovoi kommunikatsii [Semantic perception of speech message in mass communication]. Moscow: Nauka [in Russian].

Zasiekin, S.V. (2012). Psykholinhvistychni universalii perekladu khudozhnoho tekstu [Psycholinguistic universals of literary text translation]. Lutsk: Volynskyi universytet im. Lesi Ukrainky [in Ukrainian].

Zemskaia, E.A. (1993). Osobennosti muzhskoi i zhenskoi rechi [The peculiarities of male and female speech]. In E.A. Zemskaia \& D.N. Shmelev (Eds.), Russkii iazyk $i$ ego funktsionirovanie - The Russian language and its functioning. Moscow: Nauka [in Russian].

Ivanova, E.S. (2011). Verbalizatsiya emotsiy: vozrastnye i gendernye razlichiya [The verbalization of emotions: age and gender differences]. Izvestiya Uralskogo gosudarstvennogo universiteta - Izvestia Ural Federal University Journal, 4 (95), 180-188 [in Russian].

Karaulov, Iu.N. (1987). Russkii iazyk i iazykovaia lichnost [The Russian language and linguistic identity]. Moscow: Nauka [in Russian].

Kirilina, A.V. (1998). «Muzhestvennost» $\mathrm{i}$ «zhenstvennost»s tochki zreniia lingvista [«Masculinity» and «femininity» from linguistic point of view]. Zhenshchina $v$ rossiiskom obshchestve - Woman in Russian Society, 2, 21-27 [in Russian].

Kletsina, I.S. (2009). Psikhologiia gendernykh otnoshenii: teoriia $i$ praktika [The psychology of gender relations: theory and practice]. St. Petersburg: Aleteiia [in Russian]. 
Kozachyshyna, O.L. (2003). Linhvistychni proiavy hendernykh kharakterystyk anhlomovnykh khudozhnikh tekstiv (na materiali amerykanskoi prozy $\mathrm{XX}$ storichchia) [Linguistic manifestations of gender properties in English literary texts (A study of the 20-th century American fiction)]. Candidate's thesis. Kyiv [in Ukrainian].

Krasnykh, V.V. (2001). Osnovy psiholingvistiki i teorii kommunikatsii [Fundamentals of psycholinguistics and the theory of communication]. Moscow: Gnozis [in Russian].

Krasnykh, V.V. (2003). «Svoi» sredi «chuzhikh»: mif ili realnost? [One among strangers: myth or reality?]. Moscow: Gnozis [in Russian].

Kreidlin, G.E. (2005). Muzhchiny $i$ zhenzhchiny $v$ neverbalnoi kommunikatsii [Men and women in non-verbal communication]. Moscow: Iazyki slavianskoi kultury [in Russian].

Kubriakova, E.S. (1995). Evoliutsiia lingvisticheskikh idei vo vtoroi polovine XX veka (opyt paradigmalnogo analiza) [The evolution of linguistic ideas in the second half of XX century (the experience of paradigmatic analysis)]. In Iu.S. Stepanov (Ed.), Iazyk $i$ nauka kontsa XX veka - Language and science in the end of $X X$ century (pp. 144-238). Moscow: Izdatelstvo Rossiiskogo universiteta [in Russian].

Kuznetsov, M.A. (2015). Gendernye osobennosti emotsionalnoy i avtobiograficheskoy pamyati [Gender specifics of emotional and autobiographical memory]. Pravo $i$ Bezpeka - Law and Safety, 1 (56), 102-108 [in Russian].

Marchyshyna, A.A. (2015). Poetyka hendernoi identychnosti v postmodernistskomu khudozhnomu dyskursi [Gender identity poetics in postmodern literary discourse]. Naukovyi visnyk DDPU im. I. Franka - Research Journal of Drohobych Ivan Franko State Pedagogical University, 4, 102-106 [in Ukrainian].

Maslova, Iu.P. (2009). Modeli hendernoi identychnosti zhinky na storinkakh drukovanykh ZMI [The models of female gender identity in printed mass media]. Naukovi pratsi Kamianets-Podilskoho natsionalnoho universytetu im. Ivana Ohiienka - Scientific Papers of Kamianets-Podilskyi National Ivan Ohiienko University, 20, 400-403 [in Ukrainian].

Ozhgihina, E.C. (2006). Kontseptualnyi analiz reklamnogo teksta s pozitsii gendera (na materiale angliyskogo yazyka) [The conceptual analysis of an advertising text from gender perspective (based on the English language material)] Candidate's thesis. Ufa [in Russian].

Permiakova, O.V. (2007). Iavlenie gendernoi stilizatsii v sovremennoi zhenskoi literature (na materiale frantsuzskogo i russkogo iazykov) [Gender stylization in modern female literature (case study: The French and Russian languages)]. Candidate's thesis. Perm [in Russian].

Pogrebnaia, O.V. (2006). Mir russkogo zhenskogo romana (1860-1880 gg.) [The universe of Russian female romance (1860-1880)]. Zaporozhye: ZNU [in Russian].

Riutkenen, M. (2000). Gender i literatura: problema «zhenskogo pisma» i «zhenskogo chteniia» [Gender and literature: The problem of «female writing» and «female reading»]. Filologicheskie nauki - Philological sciences, 3, 5-17 [in Russian].

Selivanova, O.O. (2010). Linhvistychna entsyklopediia [Linguistic encyclopedia]. Poltava: Dovkillia [in Ukrainian].

Sternin, I.A. (2003). K razrabotke modeli kontrastivnogo opisaniia natsionalnogo kommunikativnogo povedeniia [To the model development of contrastive 
description of national communicative behavior]. In V.I. Karasik \& N.A. Krasavskii (Eds.), Aksiologicheskaia lingvistika: problem kommunikativnogo povedeniia - Axiological linguistics: the problems of communicative behavior. Volgograd: Peremena [in Russian].

Ushakova, M.Y. (2006). Gendernye osobennosti rechi detey doshkolnogo vozrasta [Gender peculiarities of children's speech at preschool age]. Candidate's thesis. Irkutsk [in Russian].

Filonenko, C.O. (2011). Massova literatura v Ukraini: dyskurs/gender/zhanr [Mass literature in Ukraine: discourse/gender/genre]. Donetsk: LANDON-XXI [in Ukrainian].

Allan, K., \& Burridge, K. (2006). Forbidden Words. Taboo and censoring in English. Cambridge: Cambridge University Press. https://doi.org/10.1017/ CBO9780511617881

Bem, S.L. (1993). The lenses of gender: Transforming the debate on sexual inequality. New Haven: Yale University Press.

Brown, P., \& Levinson, S. (1987). Politeness: Some universals in language use. Cambridge: Cambridge University Press. https://doi.org/10.1017/ CBO9780511813085

Cixous, H. (1986). The Newly Born Woman. Manchester: Manchester University Press. Claire, E. (1998). Dangerous English 2000. Los Angeles: Delta Publishing Company.

Coates, J., \& Cameron, D. (1989). Women in Their Speech Communities. New York: Longman.

Coates, J. (1986). Women, men and language. New York: Longman.

Dovidio, J., Heltman, K., Brown, C., Ellyson, S., \& Keating, C. (1988). Power displays between women and men in discussions of gender-linked tasks: a multichannel study. Journal of Personality and Social Psychology, 55 (4), 580587. https://doi.org/10.1037/0022-3514.55.4.580

Gordon, V. (1990). Love Thy Neighbour. London: Harlequin Books.

Graham, L. (2005). Crime of passion. Richmond: Mills and Boon.

Greenwood, L. (2002). Family Merger. New York: Silhouette Books.

Holmes, J. (1995). Women, men and politeness. New York: Longman.

Jespersen, O. (1922). Language, its Nature and Origin. London: Unwin Brothers.

Ker, M. (2003). Ruthless Husband, Convenient Wife. London: Harlequin Books.

Ker, M. (2004). The Millionaire Boss's Mistress. New York: Harlequin Books.

Key, M.R. (1975). Male/Female Language. New Jersey: Lawrence Eribaum.

Lakoff, R. (1973). Language and Women's Place. Language in Society, 2 (1), 45-80. https://doi.org/10.1017/S0047404500000051

Maltz, D., \& Borker, R. (1982). A Cultural approach to male-female miscommunication. In J.J. Gumperz (Ed.), Language and social identity (pp. 196-216). New York: Cambridge University Press. https://doi.org/10.1017/CBO9780511620836.013

Merritt, J. (2001). The Kincaid Bride. Richmond: Silhouette Books.

Mortimer, C. (1993). Return Engagement. Richmond: Mills and Boon.

Roberts, N. (2002). Sea Swept. London: Piatkus.

Romaine, S. (1999). Communicating Gender. London: Oxford University Press. https://doi.org/10.4324/9781410603852

Sanderson, G. (2008). Nurse Bride, Bayside Wedding. New York: Harlequin Books.

Soriano, F., Fumagalli, J., Shalom, D., Barreyro, J.P., \& Martínez-Cuitiño, M. (2016). Gender differences in semantic fluency patterns in children. East European Journal of Psycholinguistics, 3 (2), 92-102. doi: 10.5281/zenodo.267879 
Мовленнєва поведінка комунікантів в контексті тендерної...

Steckler, N., \& Rosenthal, R. (1985). Sex differences in nonverbal and verbal communication with bosses, peers and subordinates. Journal of Applied Psychology, 70 (1), 157-163. https://doi.org/10.1037/0021-9010.70.1.157

Tannen, D. (1990). You just don't understand: Women and men in conversation. New York: William Morrow.

Tannen, D. (Eds.). (1993). Gender and conversational interaction. New York: Oxford University Press.

Williams, L. (1990). Spirits Willing. London: Harlequin Books.

Woods, S. (2000). The Print-Sized Secret. Richmond: Silhouette Books.

\begin{abstract}
АНОТАЦІЯ
Метою дослідження $\epsilon$ виявлення й аналіз специфічних ознак персонажного мовлення крізь призму гендерної ідентичності. Студія проводиться у двох напрямках з точки зору співвідношення й взаємодії реального та фікціонального текстоутворюючих суб'єктів: гендерної ідентичності автора й створеного ним художнього образу.
\end{abstract}

Прочедура дослідження включає застосування дискурс-аналізу, що дозволило глибоко зануритись в особливості проеціювання на елементи мовленнєвої організації тексту психологічних і соціокультурних чинників. Комбінація методів контент- та елементів інтент-аналізу дало можливість з'ясувати прагматичні інтенції письменника в процесі створення комунікативного повідомлення.

В результаті наукової праці було вивчено теоретичні засади гендерно зумовленої комунікативної поведінки і диференційовано специфічні риси гендерного комунікативного стилю. Зокрема, встановлено, що табуйована лексика належить до тих глибинних ознак чоловічого і жіночого мовлення, що важко сфальсифікувати. Подальший аналіз вживання некодифікованих слів виявив, що в романах авторів-жінок наявні гендерні стереотипи диктують вибір мовних засобів для створення вербального образу ідеального чоловіка i жінки: нехтування моральними приписами (превалювання забороненої лексики, спрямованої на конфлікт, змагальну й домінуючу взаємодію) й дотримання існуючих комунікативних норм (незначна кількість табу-слів, загальна спрямованість комунікації на кооперацію й взаємодію) відповідно. Ґендерна диреренціація використання табуйованого лексикону в творах авторів-чоловіків суперечить загальноприйнятому стереотипу застосування табу переважно чоловіками. Зазначено, що ці відмінності пов'язані з явищем гендерної стилізації. Встановлено, що стильова імітація стереотипних особливостей мовлення особи протилежної статі відбувається у двох напрямках: автори-жінки стилізують висловлювання персонажів відповідно до маскулінного комунікативного стилю за рахунок переважання табуйованої лексики; автори-чоловіки свідомо імітують фемінну манеру письма шляхом пом'якшення висловлювань персонажів обох статей.

Зроблено висновок, що поряд з імітованими рисами у текстах виявляються ідентифікуючі ознаки справжньої ґендерної ідентичності автора - превалювання 
табуйованих лексем "damn» ma «hell» в комунікації різностатевих дійових осіб у текстах авторів-чоловіків на відміну від вербальної поведінки чоловічих та жіночих персонажів у текстах авторів-жінок.

Ключові слова: гендерна комунікативна поведінка, гендерний комунікативний стиль, гендерна стилізація, гендерна ідентичність, фемінне/маскулінне мовлення, персонажне мовлення, авторська інтенція.

\section{Адаменко Ольга \& Клименко Ольга. Речевое поведение коммуникантов в контексте гендерной идентичности (на материале англоязычного любовного романа)}

\section{АННОТАЦИЯ}

Целью исследования является выявление и анализ специфических признаков персонажной речи сквозь призму гендерной идентичности. Исследование проводится в двух направлениях с точки зрения соотношения и взаимодействия реального и фикционального текстообразующих субъектов: гендерной идентичности автора и созданного ним художественного образа.

Процедура исследования включает применение дискурс-анализа, что позволило глубоко погрузиться в особенности проецирования на элементы речевой организации текста психологических и социокультурных факторов. Комбинация методов контент- и элементов интент-анализа дала возможность выяснить прагматические интенции писателя в процессе создания коммуникативного сообщения.

В результате научной работы был изучен теоретический базис гендерно обусловленного коммуникативного поведения и дифреренцированы специфические признаки гендерного коммуникативного стиля. В частности, установлено, что табуированная лексика принадлежит к тем глубинным особенностям мужской и женской речи, которые трудно сфальсифицировать. Дальнейший анализ употребления некодифицированных слов показал, что в романах авторов-женщин присутствующие гендерные стереотипы диктуют выбор языковых средств для создания вербального образа идеального мужчины и женщины: пренебрежение моральными устоями (преобладание запрещенной лексики, направленной на конфликт, соревновательное и доминирующее взаимодействие) и соблюдение существующих коммуникативных норм (незначительное количество слов-табу, общая направленность коммуникации на кооперацию и взаимодействие). Гендерная дифференциация использования табуированного лексикона в произведениях авторов-мужчин противоречит общепринятому стереотипу использования табу преимущественно мужчинами. Отмечено, что это несоответствие связано с явлением гендерной стилизации. Установлено, что стилевая имитация стереотипных особенностей речи противоположного пола происходит в двух направлениях: авторы-женщины стилизируют высказывания персонажей соответственно с маскулинным коммуникативным стилем за счет превалирования 
табуированной лексики; авторы-мужчины сознательно имитируют феминную манеру письма путем смягчения высказываний персонажей обох полов.

Сделан вывод, что, наряду с имитированными чертами, в текстах проявляются идентифицирующие признаки настоящей гендерной идентичности автора - превалирование табуированных лексем damn u hell в коммуникации разнополых действующих лиц в текстах авторов-мужчин в отличие от вербального поведения мужских и женских персонажей в текстах авторов-женщин.

Ключевые слова: гендерное коммуникативное поведение, гендерный коммуникативный стиль, гендерная стилизация, гендерная идентичность, феминная/маскулинная речь, персонажная речь, авторская интенция. 